\title{
Acceptance, Filter and Counter Information Contain Hate Speech among the Newly Elected Voters on Election Issues
}

\author{
Deddy Irwandy ${ }^{1}$ and Rani Chandra Oktaviani ${ }^{2}$ \\ Sekolah Tinggi Ilmu Komunikasi-LSPR \\ Jakarta, Indonesia \\ 1'deddy.i@1spr.edu, ${ }^{2}$ rani.co@1spr.edu
}

\begin{abstract}
Hate speech has become a relatively new phenomenon felt by the Indonesia people. This is evident in the release of the Chief of Police memo on Hate speech in 2015. The behavior of spreading hate speech has long been done during the elections in Indonesia; through negative or black campaigns in local elections. This also happened before the election of governor (pilkada) in Jakarta in February 2017.The purpose of this research is to know the characteristics of process of Hate Speech loaded information among new voters on election issue. The speech act theory developed by Habermas of Austin and Searle's became one of the basis for analyzing hate speech in this research. The methodology used in this study uses an approach with indepth interviews on new voters who actively take part in social and religious organizations. The results show that there are three stages experienced by the new voters because of the exposure of hate speech, which are Acceptance (Information Reception), Filter (Filtering Information), and Counter (Defying Information). The typical characteristics of the new selectors in the Acceptance stage, tend to receive information from social media based on real time channels, open, share and are they accelerate. While at Filter stage they tend to choose information based on idealism, social and religious background, group affiliation, media literacy and certain figures. Whereas in the third stage, the new voters tend to defy information any containing hate speech by rejecting information, comparing other facts, looking for agreement and resistance movement.
\end{abstract}

Keywords-Hate Speech, Beginner Voters, Election

\section{INTRODUCTION}

The State of Indonesia experienced a very rapid process of democratization since the fall of President Soeharto's regime in 1998. All societies based on nationalist and religious can now participate in the democratization process and communities throughout Indonesia have the choice to support their leadersor not. The democratization process has an impact on the pattern of community interaction, which is to create decentralization and sharpen the competition between local actors from various communities and identity groups to gain power at the provincial and district / city levels. The emergence of communities, organizations and groups of identities-political parties, militant groups and religious organizations-whose actions, albeit uncoordinated, have created an enabling environment of hate among the people.
Democratization has important consequences for hard-line identity groups, communities and organizations. On the one hand, the new openness in Indonesia gives flexibility to these groups. But on the other hand, they cannot easily master and gain a place in the community. They must continue to compete with other different groups. Therefore, the rise in religiosity is not always expressed with intolerant or exclusive attitudes.

The target of the emergence of the community, this hardline identity group is the beginner voters who have not had the experience of the ongoing process of democratization. Beginner voters are stretched to immature ages where they are subjected to propaganda from the communities, organizations and identity groups to get their votes. So the message conveyed to the novice voter has an absolute content that emphasizes that the identity group, organization or community is the most correct, besides targeting the psychological element of the beginner voters.

The enthusiastic voter spirit in following the democratic process is utilized by spreading incorrect messages on social media such as twitter, facebook, instagram, youtube and other instant messaging. The message information contains an unclear hatred of the truth and its source. But they accept as a truth because they get and circulate information from identity groups, communities and organizations.

What's more interesting is how these beginner voters behave over the information they receive from the community, the identity group and the organization in their choice? So this research leads to research objectives to find out how the beginner voters process the exposure of information in the form of acceptance, screening and rejection form, from hate speech received.

\section{RESEARCH METHOD}

\section{A. Theoritical Framework}

The speech act theory developed by Habermas of Austin and Searle's thinking, became one of the foundations for analyzing hate speech in this research. Speech acts underlying the notion that every word or language must be understood as an act consisting of two things, namely as a proportional activity (effort to demonstrate facts) and performative (an effort to give understanding to the recipient of the message). 
Austin's speech act theory, however, theoretically distinguishes the language, the present speech situation, and the intentions of the present speaker [1].

The theory that became the shade of this research is the theory of speech act, where this theory has proximity to the realm of communication, especially in the delivery of messages. The relevance of speech act theory to this research is related to the object of research that is spreading hate speech, which is part of the study of language in this case the content, the context of the situation of the dissemination of information especially in the period of general election, until the intention of delivery of the message is behind it. However, this research point of view focuses on the communication process on the message recipient (Hate Speech)

Hate speech define as all forms of expression which spread, incite, promote or justify racial hatred xenophobia, antisemitism or other forms of hatred based on intolerance, including : intolerance expressed by aggressive nationalism and ethnocentrism, discrimination and hostility against minorities, migrants and people of immigrant origin [2].

Referring to the hate speech concept above, illustrates that the phenomenon that developed during the election at both the local and national levels into the realm of hate speech. various actions that lead to communication activities and hate speech with diverse purposes, such as promotional forms, public opinion rendering, racial messages, to the discrimination of certain groups.

The study also cites the term hate speech as an attempt to make space in the discourse on democracy, in which we recognize one type of market failure in the market of ideas that erodes one of the basic pillars of democratic life. Some important points that can be taken in the statement is the expression of hatred as a product of discourse, and usually appears in the democratic process [3]. Hate speech arises from the existence of a false reality that seeks to build on the interests of a particular party, coalition, or group. As in the current elections in Indonesia, where the climate of political communication is democratic, has the effect of the emergence of political discourses are inserted in various themes, such as race issues, ideological issues, to religious issues.

In the communication process there is a process of delivering information where the recipient will go through three stages, receive, filter or select and lead to rejection. As stated in the political communication literature cited 3 main points that voters tend to receive political information and attitude in the form of 1 . Selective processing of information, 2. Message Acceptance 3. Message Rejection [4]. So later to see how the process of receiving hate speech among beginner voters will refer 3 points above.

\section{B. Methodology}

This study, using a qualitative approach on the grounds that this method can dig information to each informant in depth. The approach under the constructive paradigm is used on the basis that the existing phenomena are natural and can be confirmed to the social actors. Descriptive data into output in this study to describe every stage / process of communication that runs in the community, especially in the context of the problem taken is the acceptance of hate speech which is currently a significant problem to be examined.

The data collection techniques are conducted in-depth interviews. Data that have been collected are further classified according to the research objectives. Data analysis phase used from Miles and Huberman with the following stages [5]:

1) Data Reduction;

2) Presentation of Data;

3) Withdrawal Conclusion / Verification.

The results of the analysis will be summarized to provide an overview of the communication stage after receiving hate speech messages in the form of Reception, Filtering and Rejection. The time of research is August - November 2017.

\section{RESUlT AND DISCUSSION}

The results show that there are three stages experienced by the new voters because of the exposure of hate speech, which are Acceptance (Information Reception), Filter (Filtering Information), and Counter (Defying Information). Beginner voters in the freedom of information have an opportunity to obtain information that varies, exposure to information sometimes does not have to be searched but rather passively through the social media page.

From the communication process there are 3 stages related to the process of receiving information such as how the voters receive hate speech messages based on the results of research shows The typical characteristics of the new selectors in the Acceptance stage, Tend to receive information from social media based on:

1. Real time channels, visible actually not a beginner selector who actively seek information, but exposure of information through social media that makes beginner voters get access to information in a relatively fast time. In addition to the system of friendship and social networking to make novice voters share information at the same time.

2. Open, Young start-up voters are more open-minded with all the information they choose not as in conventional media patterns such as newspapers, their tendency to have at least 4-5 social media, making them open to information relating to election issues or area. They also know that the hate speech sometimes not necessarily clear source and direction information. As stated in the quotation of resource persons below:

"Pernah di media social, tapi bukan dari komunitas
atau Lembaga lainnya, saya pernah melihat dari
seseorang, tentang postingannya di intagram, yang
menjelekkan salah satu paslon."

3. Share, the next characteristic of young voters is the tendency after receiving the information, they will disseminate information at least to one group that is considered the nearest environment. The environment can be in a particular family, friendship, or community. 
4. Accelerate. The other specialties of beginning voters in sharing information put speed ahead, as part of the actuation so they assume that if they can continue quickly they will get feedback on the information.

In the second communication process, after they receive the hate speech message, the novice voters turns to a growing information screening process.

At the Filter stage they tend to choose information based on:

1. Idealism, there are some novice voters who filter the information hate speech based ideology or understand the basic reference of the leader figure. So when there is information that leads to a certain understanding may be voters to agree or disagree with hate speech. So that ideology can be a filter of information received hate speech, as presented by resource persons in this research:

“..ada yang saya percaya ada juga yang saya perlu filter. Misalnya pernah dia bilang itu, PKI itu apa-apa yang di Indonesia itu tidak boleh sama sekali. Nah saya jadi mikir, sebenernya PKI itu separah apa sampai Indonesia gak boleh dimasukkin PKI.. tapi kalau secara Ideologi kan memang salah karena bertentangan dengan sila pertama dari Pancasila. Terus dia bilang, "kalau ada PKI usir aja!" nah itu yang buat saya mungkin agak saring...

2. Social and Religious Background, in addition, this time is also quite noticeable is the beginner voters make the issue of religion and social environment. When the content of the hate speech content has converted to a particular religion or social community usually here the voters will go through the process of filtering information.

"hmm saya sih milih siapa aja, tapi selama dia ngusik keimanan, ya pasti saya gak mau milih. Kalau misalkan kondisinya saya tinggal di Amerika (serikat), dan saya harus memilih Presiden Amerika yang which is non muslim, saya pasti bakal milih tapi (saya lihat) mana yang lebih friendly ke muslim. Mana yang lebih toleran lah ke Islam."

3. Group Affiliation, the influence of the affiliate group will also determine whether the outstanding hate speech will be accepted or not. This group will be a referral group including voter electoral confirmation, when the speech hate in the language is too far with the affiliated group then they will filter as information to be rejected and vice versa.

4. Media Literacy, the process of filtering information on beginner voters is also derived from how much reading is consumed by the novice voters. The more read references they can capture the discourse of hate speech dissemination and the novice selector will tend to be neutral in responding. While in some voters, with minimal media literacy then tend to receive hate speech by returning to the social and religious background.

5. Certain Figures. Furthermore, beginner voters usually already have prominent figures, sourced from religious leaders or political leaders who will be carried, so that when they get hate speech information about these figures sometimes they will tend to ignore because for those figures that have been declared credible based on the reference he got.

Furthermore, in the third stage where voters will enter the third stage in receiving hate speech information, which based on the results of research tendency to show beginner voters in responding hate speech. The new voters tend to defy information any containing hate speech by:

1. Rejecting Information, after going through a series of information filtering then the beginner selector allows to directly reject the hate speech information. They will not read the entire hate speech when the beginning has seen its contents. They also immediately commented that the news was wrong, after receiving the information.

2. Comparing Other Facts In addition, one form defies information by directly handing out other facts through different media, requesting complete data and may even argue with other opinions that are considered as its main reference.

3. Looking For Agreement, other uniqueness is also found in this process, there is a novice selector who when receiving hate speech they seek to collective agreement to make the received message rejected or declared irrelevant to the facts information obtained. This agreement can be made by making a discussion group related hate speech received.

4. Resistance Movement, other findings are on the process of information hate speech opposition, there are also electoral voters tend to do the movement against the issue of circulating resistance, back again at the beginning of receipt of information then quite a lot of moves against when contents has influence on religious issues and race.

The findings show that novice voters today can freely accept hate speech, when referring to the context of Austin's theory that theoretically distinguishes the language, the present speech situation, and the intentions of the present speakers. The dissemination of hate speech information among novice voters is divided into how the choice of language as the contents seen by the novice voters. Then the situation of information development will depend on the situation, as the hate speech that develops in the election period will feel more viscous with political nuance and the novice voters will tend to feel that the information has a hidden interest from the maker.

In Indonesia itself, novice voters seek to gain confidence that the hate speech that circulated during the election, is part of the campaign. So the characteristics are still varied in acceptance. They also feel that the hate speech in circulation is still about language games that raise the issue of race and intolerance. This is similar to the definition of Hate speech which is as all forms of expression which spread, incite, 
promote or justify racial hatred xenophobia, antisemitism or other forms of hatred based on intolerance.

\section{CONCLUSION}

Based on the results of research indicates that beginner voters tend to get various information related to general election both at local and national level from various channel of information. In the Acceptance stage, tend to receive information from social media based on real time channels, open, share and are accelerate. While at Filter stage they tend to choose information based on idealism, social and religious background, group affiliation, media literacy and certain figures. Whereas in the third stage, the new voters tend to defy information any containing hate speech by rejecting information, comparing facts, looking for agreement and resistance movement.

The implication of this research result is to show that the novice voters, currently have the capacity as determinant in the general election process, where before participating in the election they try to actively get information about the sorting activities, but because of the hate speech can be considered. Allow hate speech to be the guidance of the election or they directly reject the information directly.

This research also shows that the condition of beginner voters still pay attention to the content of hate speech based on the principles and ideology of beginner voters. Also that the understanding of hate speech by beginner voters, still very contextual, in this case like power, history and religion.

\section{REFERENCES}

[1] Oishi, E. (2006). Austin's Speech Act Theory and the Speech Situation. Austin's Speech Act Theory and the Speech Situation, pp. 1-14.

[2] Michael herz, P. m. (2012). The Content and Context of Hate Speech: Rethinking Regulation and Responses. United States America: Cambrige University Press.

[3] George, C. (2017). Pelintiran Kebencian. Jakarta: Pusat Studi Agama dan Demokrasi.

[4] Perloff, B. I. (2004). Political Marketing: Theory,. In L. L. Kaid, Hanbook Political Communication Reserach (p. 31). New Jersey: LAWRENCE ERLBAUM ASSOCIATES, PUBLISHERS.

[5] Lincoln, D. a. (2009). Hanbook of Qualitative Research . Yogyakarta: Pustaka Pelajar. 